\title{
An "ordinary" case of COVID-19 pneumonia: when symptoms hide serious complications
}

\author{
Francesco Messinaa, Marianna Gigliotti De Faziob, Claudia Morabito ${ }^{b}$, \\ Roberto Licordarib, Cristina Procopio Mariab ${ }^{b}$ Maurizio Mezzettic, \\ Paolo Busaccac, Giuseppe Dattilob, Nicola Arcadia, Matteo Casalec
}

a Operative Unit of Radiology - G.O.M. Bianchi Melacrino Morelli, Reggio Calabria, Italy

${ }^{b}$ Department of Clinical and Experimental Medicine, University of Messina, Messina, Italy

" Hospital "S. Maria della Misericordia", Operative Unit of ICCU and Cardiology, ASUR Marche-Area Vasta 1, Urbino, Italy

ARTICLE INFO

Article history:

Submitted: 6. 12. 2020

Accepted: 2. 1. 2021

Available online: 23. 9. 2021

\section{Klíčová slova:}

COVID-19

Nízkomolekulární heparin

Plicní embolie

SARS-CoV-2

Vyšetření hrudníku výpočetní

tomografií

Keywords:

Chest computed tomography COVID-19

Low molecular weight heparin

Pulmonary embolism

SARS-COV-2

\section{SOUHRN}

Pandemie v podobně onemocnění COVID-19 rychle změnila klinický obraz světa. Symptomy se často dostavují plíživě a maskují dramatické klinické scénáře. Na oddělení akutního př́ijmu byl dopraven 52letý muž s perzistentní bolestí na hrudi, dyspnoe a hypoxií. Stěžoval si rovněž na kašel a horečku $\left(38^{\circ} \mathrm{C}\right)$ pretrvávající už čtyři dny bez jakéhokoli klinického zlepšení při užívání paracetamolu. Nazofaryngeální stěr byl pozitivní na přitomnost viru SARS-CoV-2. Vyšetření výpočetní tomografií s vysokým rozlišením (high-resolution computed tomography, HRCT) ukázalo typický obraz oboustranného zápalu plic v souvislosti s onemocněním COVID-19. Během pobytu v nemocnici došlo ke zhoršení klinického stavu pacienta a CT angiografické vyšetření plic prokázalo bilaterální masivní akutní plicní embolii. Byla zahájena léčba nefrakcionovaným heparinem.

(c) 2021, ČKS.

\begin{abstract}
COVID-19 pandemic changed quickly world's clinical picture. Symptoms often are sneaky, hiding dramatic clinical scenarios. A 52-year-old man was sent to the Emergency Department with persistent chest pain, dyspnea and hypoxia. He also complained of cough and fever $\left(38^{\circ} \mathrm{C}\right)$ since four days without clinical improvements by paracetamol. Nasopharyngeal swab was positive for SARS-CoV-2. High resolution computer tomography (HRCT) showed typical CT pattern of bilateral COVID-19 pneumonia. During hospital stay clinical worsening occurred and a CT pulmonary angiography revealed a bilateral massive acute pulmonary embolism. The patient was treated with unfractionated heparin.
\end{abstract}

\section{Introduction}

Novel coronavirus pandemic leads to heterogeneous clinical expression referred as coronavirus disease 2019 (COVID-19). In some patients the clinical course could be dramatic, leading to respiratory distress and respiratory failure. This clinical manifestation is the origin of the expression "severe acute respiratory syndrome coronavirus-2" (SARS-CoV-2). While in most cases the clinical course is silent, those patients experiencing moderate to severe forms need long hospitalizations, limiting the ordinary availability of hospital beds and posing an impor- tant challenge to healthcare providers even in terms of optimal management. ${ }^{1}$ Use of computed tomography (CT) imaging in diagnosis and follow-up has rapidly grown, allowing better knowledge of radiological evolution. To date CT is the first-line imaging tool ${ }^{2}$ and showed its usefulness in diagnosis even in case of false negative initial screening by polymerase chain reaction. ${ }^{3}$ Current guidelines in fact encourage use of chest CT for diagnosis, severity assessment and monitoring of COVID-19 but patients with sudden clinical deterioration and worsening of dyspnea or chest pain may benefit from vascular evaluation by contrast medium. 


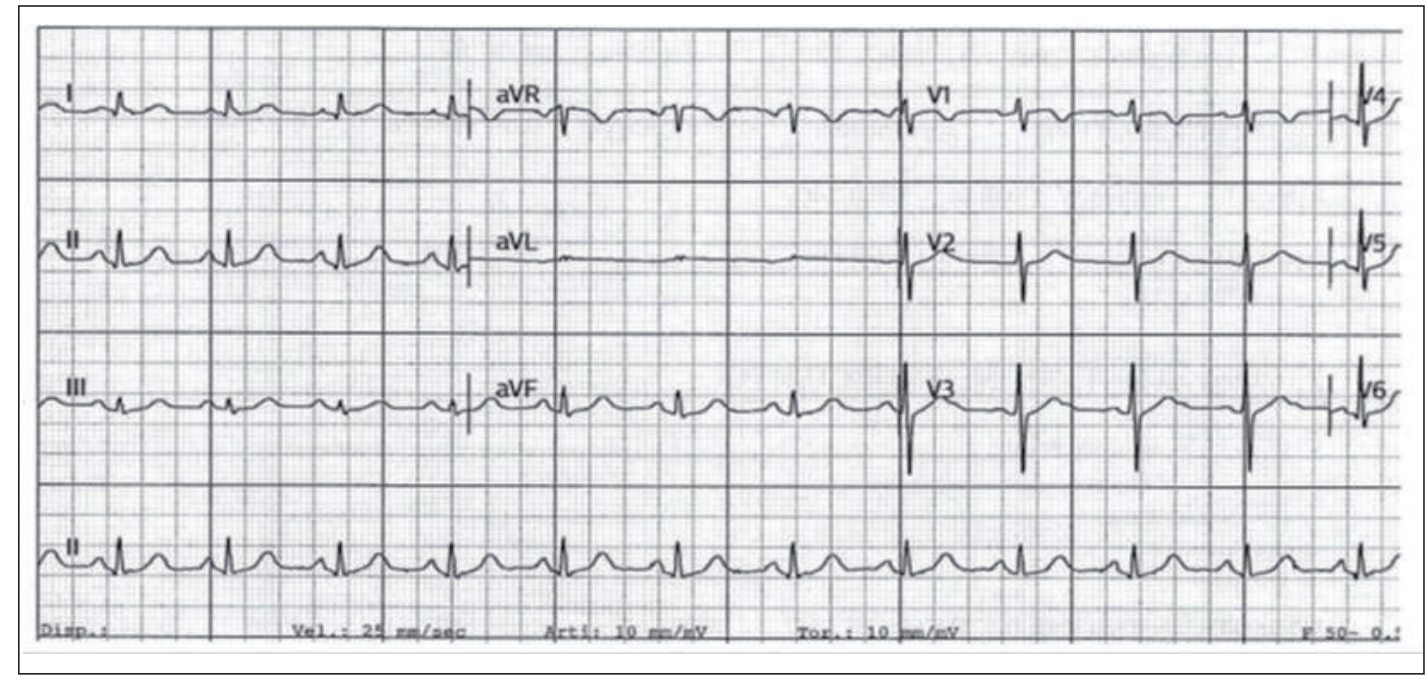

Fig. 1 - Normal baseline ECG of the patient.

\section{Case report}

During the first phase of the pandemic in March 2020 a 52-year-old man arrived to the Emergency Department complaining of persistent chest pain, dyspnea, cough and fever $\left(38,5^{\circ} \mathrm{C}\right)$ since four days, without clinical improvements by paracetamol. In anamnesis he reported to suffer from arterial hypertension, type 2 diabetes mellitus, myelodysplastic syndrome. In the Emergency Department a blood gas analysis revealed a saturation of $90 \%$. Lung murmur was significantly reduced bilaterally. Blood tests showed leukopenia (3.3 g/L); thrombocytopenia (129 g/L); increased C-reactive protein $(220 \mathrm{mg} / \mathrm{L})$, lactate dehydrogenase $(350 \mathrm{mU} / \mathrm{mL})$, procalcitonin $(10 \mathrm{ng} / \mathrm{mL})$ and $D$-dimer $(450 \mathrm{mg} / \mathrm{dL})$. A cardiac evaluation was performed. Baseline ECG was normal (Fig. 1) and echocardiogram was limited by high acoustic impedance, showing a left
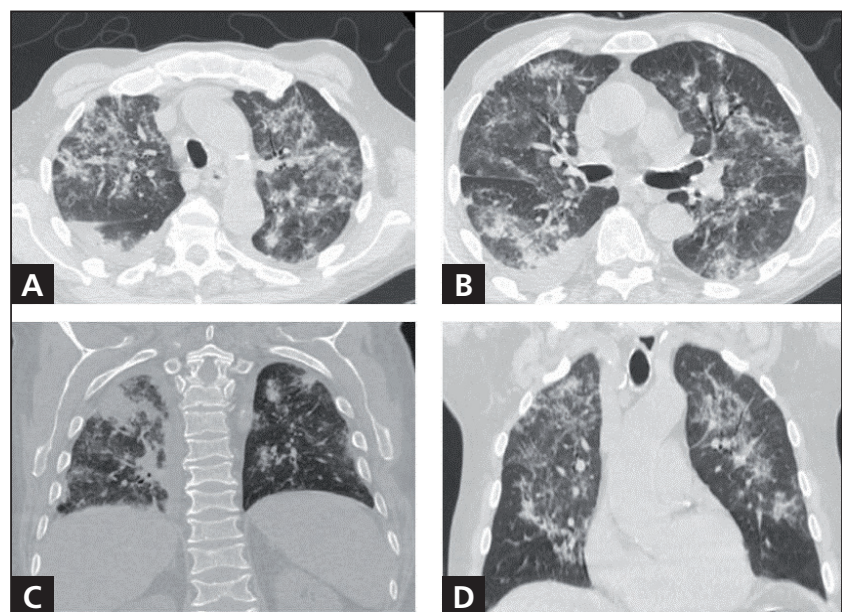

Fig. 2 (A-D) - HRCT pattern of bilateral COVID-19 pneumonia of the patient. Bilateral and multifocal ground glass findings predominantly localized in all pulmonary lobes; basal sub-pleural fibrotic striae in both lungs; bilateral pulmonary interstitial thickenings; consolidations in the posterior-basal segments of right and left lower lobes and right pleural effusion.
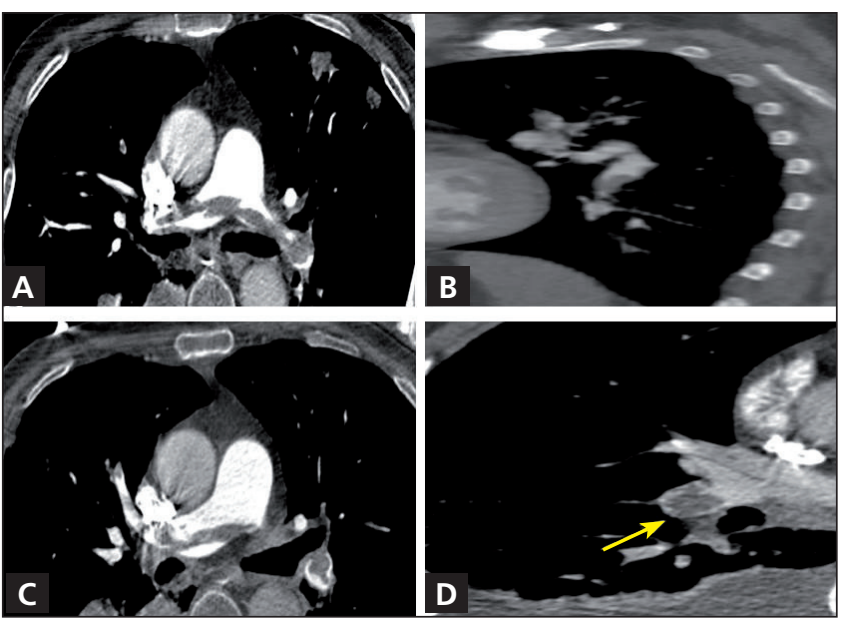

Fig. 3 (A-D) - CT pulmonary angiography revealed a bilateral massive acute pulmonary embolism. In (D) a short axis of the main pulmonary artery with riding thrombus (arrow).

ventricle normal ejection fraction with only a mildly hypokinetic right ventricle (TAPSE was $15 \mathrm{~mm}$ ) and a pulmonary arterial pressure of $50 \mathrm{mmHg}$. A nasopharyngeal swab was positive for SARS-CoV-2.

A high resolution chest CT (HRCT) was performed, showing bilateral and multifocal ground glass opacity predominantly located peripherally in all five pulmonary lobes; basal sub-pleural fibrotic streaks in both lungs; bilateral pulmonary interstitial thickenings; consolidations in the posterior-basal segments of right and left lower lobes, and right pleural effusion (Fig. 2). All these signs were suggestive for bilateral COVID-19 pneumonia and the patient was hospitalized and empirical therapy with lopinavir/ritonavir, azithromycin, and hydroxychloroquine was started.

Two days after there was a clinical worsening. Because of increasing blood levels of D-dimer $(1.020 \mathrm{mg} /$ $\mathrm{mL}$ ) CT pulmonary angiography was urgently performed. The scan showed the presence of extensive hypodense filling defect, compatible with massive bilateral pulmo- 
nary embolism (Fig. 3), riding the common trunk of the pulmonary artery and extending through right and left branches (Fig. 3D) up to the main segmental branches of the upper and lower right lobes and of the left lower lobe (Fig. 3B).

On these bases infusion therapy with unfractionated heparin was started in association with non-invasive oxygen therapy with a positive end expiratory pressure (PEEP) of $7.5 \mathrm{mmHg}$. After few days blood gas improved and oxygen therapy was progressively reduced. He was discharged after 20 days.

\section{Discussion}

This case is focused on the difficulties in management of COVID-19 patients. There is increasing evidence of an association between COVID-19 and thromboembolism. ${ }^{4}$ Incidence of acute pulmonary embolism in patients with COVID-19 is currently under investigation. Cui et al. reported a thromboembolism incidence of $25 \%$ in a cohort of 81 patients with COVID-19 pneumonia ${ }^{5}$ but coagulation disorders may occur anyway in patients with severe symptoms. ${ }^{6}$ In fact SARS-CoV-2 is associated with a high prevalence of coagulopathy almost in all those critically ill patients, ${ }^{7}$ leading to major thromboembolic events, such as pulmonary embolism. ${ }^{8}$

In the last months use of low molecular weight heparin (LMWH) increased, especially in critically ill patients, and currently several trials are ongoing to test the best dose. To date the International Society on Thrombosis and Haemostasis (ISTH) advocates the use of laboratory tests, including D-dimers, prothrombin time, and platelet count to stratify the risk during hospital admission. ${ }^{7}$ According to the same ISTH interim guidance all in-patients should receive antithrombotic prophylaxis with $\mathrm{LMWH}$, unless contraindicated. ${ }^{7}$ However, while a full anticoagulant dose of LMWH is currently not recommended for each patient, an early antithrombotic strategy to prevent thromboembolism could improve clinical course in some patients.., 10

In concomitance chest CT has quickly become a cornerstone both in early diagnosis and during follow-up. ${ }^{11}$

While before the pandemic there was a general consensus on extensive use of bedside echocardiography as a first line tool both for assessment of left and right ventricle, ${ }^{12,13}$ to date this point of view is reversed. In fact there are important concerns on extensive use of bedside echocardiography: a) usefulness in terms of therapy variations; b) intrinsic limitations to detection pulmonary embolism; c) operator safety. ${ }^{14}$ In this context clinical judgement and D-dimer test, both on admission and during hospital stay, are the best (and possibly more rapid) tools to early suspect pulmonary embolism. Those patients judged to be at high risk should be always evaluated by use of contrast medium during chest CT.

In this case unfractionated heparin was used but optimal dose and cases of LMWH failure have been reported. ${ }^{15,16}$ Furthermore more evidence is currently needed in case of other concomitant cardiac conditions such as patent foramen ovale, cardiac devices, advanced heart failure or younger age. ${ }^{17-20}$
Our case shows that it is possible to make an appropriate follow-up and therapy of patients even without extensive use of bedside echocardiography in COVID-19 patients. While its high availability and easiness made an ideal first line diagnostic tool to date this point of view should be somewhat reevaluated.

\section{Conclusions}

COVID-19 changed the way we think. Symptoms often hide dramatic clinical scenarios due to concomitant pulmonary embolism. While several uncertainties still remain (such as the proper dose of LMWH for each patient, the role of DOAC, the optimal management of concomitant diseases), we learnt about the role of chest CT compared to chest X-ray. Furthermore extensive use of bedside echocardiography is not required or advisable because of lack of clinical benefit and because of operator's safety. The challenge of COVID-19 is that every single aspect of modern medicine needs more accurate evaluation than before and clinical judgement still remains the cornerstone of medicine.

\section{Acknowledgements}

None.

\section{Conflict of interest}

None.

\section{References}

1. Wang D, Hu B, Hu C, et al. Clinical characteristics of 138 hospitalized patients with 2019 novel coronavirus-infected pneumonia in Wuhan, China. JAMA 2020;323:1061-1069.

2. Ai T, Yang Z, Hou H, et al. Correlation of Chest CT and RT-PCR Testing for Coronavirus Disease 2019 (COVID-19) in China: A Report of 1014 Cases. Radiology 2020;296:E32-E40.

3. Xie X, Zhong Z, Zhao W, et al. Chest CT for Typical Coronavirus Disease 2019 (COVID-19) Pneumonia: Relationship to Negative RT-PCR Testing. Radiology 2020;296:E41-E45.

4. Zhai Z, Li C, Chen Y, et al. Prevention and Treatment of Venous Thromboembolism Associated with Coronavirus Disease 2019 Infection: A Consensus Statement before Guidelines. Thromb Haemost 2020;120:937-948.

5. Cui S, Chen S, Li X, et al. Prevalence of venous thromboembolism in patients with severe novel coronavirus pneumonia. J Thromb Haemost 2020;18:1421-1424.

6. Thachil J, Tang N, Gando S, et al. ISTH interim guidance on recognition and management of coagulopathy in COVID 19. J Thromb Haemost 2020;18:1023-1026.

7. Iba T, Levy JH, Levi M, et al. Coagulopathy of Coronavirus Disease 2019. Crit Care Med 2020;48:1358-1364.

8. Casale M, Dattilo G, Imbalzano E, et al. The thromboembolism in COVID-19: the unsolved problem. Panminerva Med. 2020 Jun 16. doi: 10.23736/S0031-0808.20.03999-3. Epub ahead of print.

9. Casale M, Imbalzano E, Morabito C, et al. Early antithrombotic therapy and COVID-19: a better clinical course? New evidences from real-life cases. Cor Vasa 2020;62:37-40.

10. Dattilo G, Falanga G, Casale M, et al. Oral Anticoagulants: Old and New Therapy. In: Bernhardt LV (Ed.). Advances in Medicine and Biology. New York: Nova Science Publishers, Inc., 2015:13-70.

11. Dai WC, Zhang HW, Yu J, et al. CT Imaging and Differential Diagnosis of COVID-19. Can Assoc Radiol J 2020;71:195-200. 
12. Imbalzano E, Di Bella G, Lamari A, et al. Right ventricular myocardial deformation in young healthy subjects: A comparison study between 2D Strain and traditional parameters. Exp Clin Cardiol 2014;20:2729-2743.

13. Dattilo G, Imbalzano $E$, Lamari A, et al. Ischemic heart disease and early diagnosis. Study on the predictive value of $2 \mathrm{D}$ strain. Int J Cardiol 2016;215:150-156.

14. Ward RP, Lee L, Ward TJ, Lang RM. Utilization and appropriateness of trans-thoracic echocardiography in response to the COVID-19 pandemic. J AmSoc Echocardiogr 2020;33:691-692

15. Dattilo G, Lamari A, Di Bella G, et al. Treatment failure of low molecular weight heparin bridging therapy. Int J Cardiol 2013;167:e106-e107.

16. Tulino D, Imbalzano E, Casale M, et al. Treatment failure of low molecular weight heparin in diabetic patient. Int J Cardiol 2013;168:e63-e64.
17. Morabito C, Scarano M, Genovesi E, et al. Patent foramen ovale and paradoxical coronary artery embolism: rare event with great clinical relevance. Cor Vasa 2020:62:332-335.

18. Casale M, Quattrocchi S, Bitto R, Dattilo G. Cardiac implantable devices and takotsubo syndrome. A rare but potential eventuality. Cor Vasa 2018;60:e500-e502.

19. Casale M, Mezzetti M, Gigliotti De Fazio M, et al. Usefulness of Sacubitril/Valsartan in reduction of atrial fibrillation burden in a patient with ICD delivering inappropriate therapies. A new possibility? Cor Vasa 2020;62:336-339.

20. Casale $M$, Mezzetti $M$, Tulino V, et al. Therapy of Cardiac Arrhythmias in Children: An Emerging Role of Electroanatomical Mapping Systems. Curr Vasc Pharmacol 2018; 16:528-533. 